\title{
Indium Tin Oxide Synthesized by a Low Cost Route as SEGFET pH Sensor
}

\author{
Nirton Cristi Silva Vieira*, Edson Giuliani Ramos Fernandes ${ }^{\mathrm{a}}$, Alvaro Antonio Alencar de Queiroz ${ }^{\mathrm{b}}$, \\ Francisco Eduardo Gontijo Guimarães ${ }^{a}$, Valtencir Zucolotto ${ }^{\mathrm{a}}$ \\ ${ }^{a}$ Instituto de Física de São Carlos - IFSC, Universidade de São Paulo - USP, \\ CP 369, CEP 13560-970, São Carlos, SP, Brazil \\ 'Instituto de Ciências Exatas - ICE, Universidade Federal de Itajubá - UNIFEI, \\ CP 50, CEP 37500-903, Itajubá, MG, Brazil
}

Received: January 10, 2013; Revised: April 19, 2013

\begin{abstract}
Polycrystalline ITO films with good optoelectronics characteristics and homogeneous surface has been obtained upon annealing at $550{ }^{\circ} \mathrm{C}$ in $\mathrm{N}^{2}$ atmosphere using a low-cost chemical vapor deposition (CVD) system. The films were evaluated as $\mathrm{pH}$ sensors in separative extended gate field-effect transistor (SEGFET) apparatus, exhibiting a sensitivity of $53 \mathrm{mV} / \mathrm{pH}$, close to the expected Nernstian theoretical value for ion sensitive materials. The use of CVD process to synthesize ITO, as described here, may represent an alternative for fabrication of SEGFET $\mathrm{pH}$ sensors at low cost to be used in disposable biosensors since $\mathrm{H}^{+}$ions are the product of several oxireductase enzymes.
\end{abstract}

Keywords: ITO, CVD, pH sensor, field-effect transistor

\section{Introduction}

Indium tin oxide (ITO) has emerged as important engineering materials, since their versatile optical and electronic properties have found application in many fields including optoelectronics and photonics ${ }^{1}$. ITO semiconductors show high transmission in the visible region, high reflectance in the infrared and high electrical conductivity. Due to the latter properties, ITO has been used as optically transparent conducting electrode in a range of applications ${ }^{2-4}$. Recently, ITO films have been used as work electrode in the development of bioengineering devices such as ion sensors and biosensors ${ }^{5-7}$. The emerging sensor and biosensor technology based on ITO films has emerged as an advantageous alternative for applications in medicine $e^{8,9}$.

ITO can also be applied to detect $\mathrm{H}^{+}$ions. In this case, two types of electronic devices can be used to $\mathrm{pH}$ sensing: a conventional ion sensitive field-effect transistor (ISFET) ${ }^{10}$ and a separative extended gate FET ${ }^{11,12}$. ISFET comprises a metal oxide semiconductor field-effect transistor (MOSFET) without gate metallization, being its insulator gate in direct contact with the solution ${ }^{10}$, whereas a SEGFET comprises a chemically sensitive membrane as separative extended gate (SEG) connecting to the gate of a commercial MOSFET ${ }^{11,12}$. The latter configuration is advantageous for sensing, since the sensor is isolated from the chemical environment and can be reused.

Synthesis of ITO has been carried out by several methods, including RF magnetron sputtering ${ }^{13}$, electron ${ }^{14}$ or ion beam evaporation ${ }^{15}$, pulsed laser ablation ${ }^{16}$, sol-gel process $^{17}$ and chemical vapor deposition $(C V D)^{18,19}$. The relative simplicity and low-cost of ITO films synthesized by CVD have made this technique technologically advantageous.

\footnotetext{
*e-mail: nirton@ursa.ifsc.usp.br; nirtoncristi@gmail.com
}

This paper reports on the synthesis and characterization of ITO films to be applied as pH sensor in a SEGFET configuration using the inexpensive CVD technique at very low-cost effective procedure. Measurements of the drain current $\left(\mathrm{I}_{\mathrm{D}}\right)$ as function of the drain to source voltage $\left(\mathrm{V}_{\mathrm{DS}}\right)$ or as function of the gate to source voltage $\left(\mathrm{V}_{\mathrm{GS}}\right)$ were used to characterize the ITO films as SEGFET $\mathrm{pH}$ sensor.

\section{Experimental}

\subsection{ITO synthesis and characterization}

ITO films were deposited on glass substrates (Corning 7059) using a commercial atomizer (HuaYi Sprayer) according to the literature ${ }^{18}$. A methanol solution $(0.1 \mathrm{M})$ of indium chloride $\left(\mathrm{InCl}_{3} \cdot 3.5 \mathrm{H}_{2} \mathrm{O}, 99.99 \%\right.$, Merck) and tin chloride $\left(\mathrm{SnCl}_{4} \cdot 2 \mathrm{H}_{2} \mathrm{O}, 99.99 \%\right.$, Merck ) was prepared with $5 \mathrm{wt} \%$ of Sn concentration. Substrate temperature was fixed in $300 \mathrm{C}$ and the solution was sprayed manually on glass substrates. After deposition, ITO films were thermally treated at $550 \mathrm{C}$ in $\mathrm{N}_{2}$ atmosphere for 1 hour. Film thickness can be controlled by the amount of sprayed solution.

Surface morphology and thickness of ITO films were examined using a scanning electron microscope (SEM, model: Phillips XL 30) set at an operating voltage of 20.0 $\mathrm{kV}$. The optical transmission of the ITO films on the glass substrates were measured using a spectrophotometer (UVVis, Varian 634) in the wavelength range of 300 to $800 \mathrm{~nm}$. The study of crystalline ITO films phases were investigated by the X-ray diffraction technique (XRD) (D/MAX-200). The X-ray patterns were taken from monochromatic $\mathrm{CuK}$ radiation source $(\lambda=1.5418 \AA)$. Film resistivity was measured using the van der Pauw method ${ }^{20}$. 


\subsection{ITO as pH sensor: measurement system}

SEGFET configuration comprises two parts ${ }^{11,12}$ : the chemically sensitive membrane, formed by the ITO film (contact area of $35 \mathrm{~mm}^{2}$ ) connected to the gate terminal of a commercial MOSFET (CD4007UB) with its gate replaced by a reference electrode of silver/silver chloride $(\mathrm{Ag} / \mathrm{AgCl} /$ Sat. $\mathrm{KCl}$ ). A programmable curve tracer (Tektronix-370A) was used to record the data. Measurements of the drain current $\left(\mathrm{I}_{\mathrm{D}}\right)$ as function of the variable voltages $\left(\mathrm{V}_{\mathrm{DS}}\right.$ or $\left.\mathrm{V}_{\mathrm{GS}}\right)$ in different $\mathrm{pH}$ buffer solutions ( $5 \mathrm{~min}$ after immersion) were carried out to determine the $\mathrm{pH}$ sensitivity of the ITO films. Figure 1 shows the scheme of the SEGFET measurement system.

\section{Results and Discussion}

ITO films with thickness about $200 \mathrm{~nm}$ (estimated by profilometry) and resistivity in the order of $10^{-4} \mathrm{~W} . \mathrm{cm}$ (measured using the van der Pauw method) ${ }^{20}$ was deposited on glass substrate by CVD. In the case of ITO conducting thin film, indium oxide $\left(\mathrm{In}_{2} \mathrm{O}_{3}\right)$ based material have been doped with $\mathrm{Sn}$ to improve the electrical conductivity. Sn acts as an n-dopant material in the $\operatorname{In}_{2} \mathrm{O}_{3}$ lattice, in substitution to indium atoms, since In has valence $3^{+}$and $\mathrm{Sn}$ has valence $4^{+}$, thus adding electrons in the conduction band. Furthermore, oxygen vacancies can donor two electrons, i.e., both oxygen

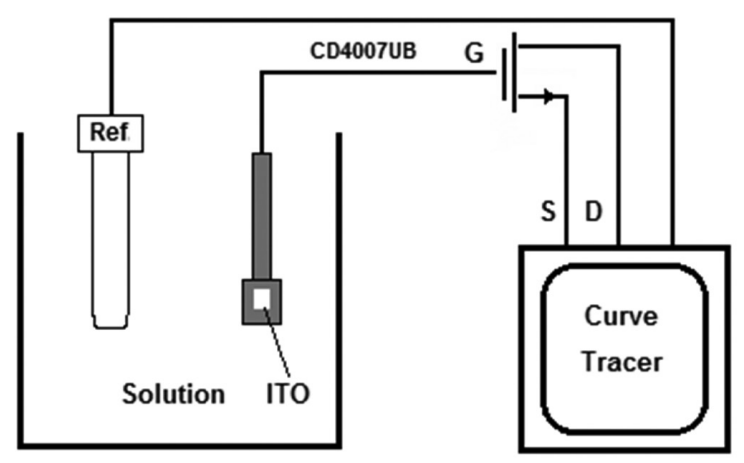

Figure 1. Scheme of the SEGFET architecture and the measurement system.

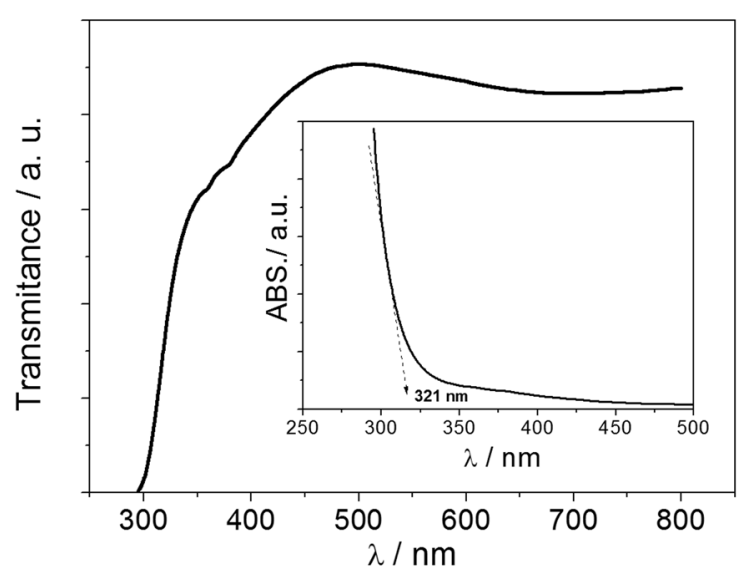

Figure 2. Transmission spectrum of the synthesized ITO film. Inset: Absorption spectrum of the same film. vacancies and the donor atoms $(\mathrm{Sn})$ contribute to improve ITO conductivity ${ }^{1,21}$.

Figure 2 shows the optical transmission spectrum of the synthesized ITO film. Optical transmittance changes significantly by increasing annealing temperature and reaches a maximum transmission for ITO films thermally treated at $550{ }^{\circ} \mathrm{C}$, in agreement to what has been reported. ${ }^{22}$ The optical absorption spectrum (Figure 2, inset) gives an estimated value for the ITO film band gap when an abrupt change in the slope of the absorbance curve is observed ${ }^{23}$. The associated band gap energy of $3.9 \mathrm{eV}$ characterizes the semiconductor properties of the material.

Figure 3 shows the XRD spectrum of the ITO film deposited onto glass substrate (for comparison, the results of $\mathrm{In}_{2} \mathrm{O}_{3}$ powders are also shown). XRD diffractograms revealed that ITO films become polycrystalline when deposited at higher substrate temperature and crystallize in a cubic bixbyite structure $\left(\operatorname{In}_{2} \mathrm{O}_{3}\right)^{24,25}$. The peaks observed for $2 \theta$ angle associated to the planes (222) and (400) may be observed. The preferential growth of the ITO films is the (222) plane and this orientation should be dependent on the deposition conditions ${ }^{25}$.

Surface morphology of the ITO films deposited onto glass substrates was examined by SEM as shown in Figure 4. After annealing at $550{ }^{\circ} \mathrm{C}$, films with a rough polycrystalline formation with grains and any voids of about $1 \mu \mathrm{m}$ in diameter were obtained. This represents a large grain misalignment, which is a very crucial requirement in thin film for electronic devices involving oxide materials.

The $I_{D}-V_{D S}$ characteristics curves of the ITO film as SEGFET $\mathrm{pH}$ sensor are shown in Figure 5a. A SEGFET operates similarly to MOSFET except that, for the former, a voltage in the reference electrode $\left(\mathrm{V}_{\mathrm{Ref}}\right)$ replaces the gatesource voltage $\left(\mathrm{V}_{\mathrm{GS}}\right)^{11,12}$. The drain current is now a function of $\mathrm{pH}$ value, since the potential on ITO surface changes due to concentration of $\mathrm{H}^{+}$in the solution. Based on MOSFET equations, in the non-linear region $\mathrm{I}_{\mathrm{D}}$ is expressed as:

$\mathrm{I}_{\mathrm{D}}=\frac{1}{2} \beta\left(\mathrm{V}_{\mathrm{GS}}-\mathrm{V}_{\mathrm{T}}\right)^{2}$

and in the linear region:

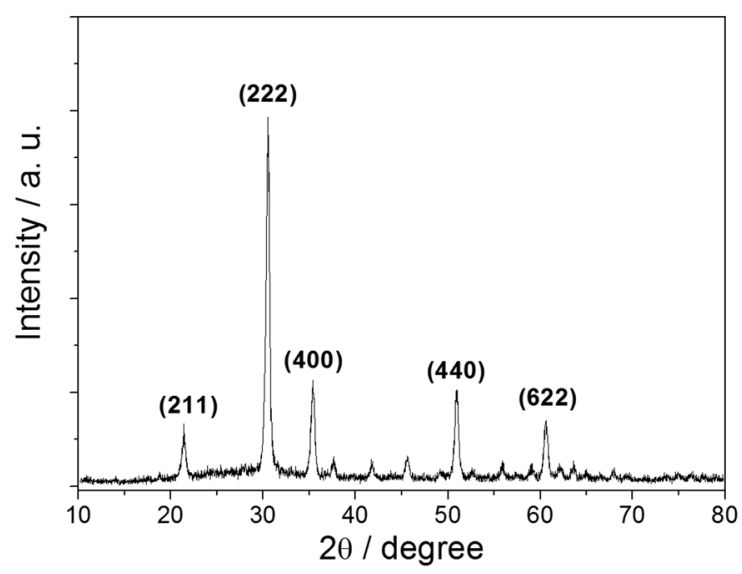

Figure 3. X-ray diffraction of ITO film deposited onto glass substrate. The peaks of the $\mathrm{In}_{2} \mathrm{O}_{3}$ powders are shown for reference. 


$$
I_{D}=\beta\left[\left(V_{G S}-V_{T}\right) V_{D S}-\frac{1}{2} V_{D S}^{2}\right]
$$

where $\beta$ is a conduction parameter, $\mathrm{V}_{\mathrm{DS}}$ is the drain - source voltage, and $\mathrm{V}_{\mathrm{T}}$ the threshold voltage, i.e. is defined as the minimum voltage required to make the transistor $\mathrm{ON}$, which is dependent on the $\mathrm{pH}$ value ${ }^{11,12}$. Based on equation $1, \mathrm{I}_{\mathrm{D}}{ }^{1 / 2}$ presents a linear $\mathrm{pH}$ response and can be expressed as a function of $\mathrm{pH}$ value, as seen in Figure $5 \mathrm{~b}$.

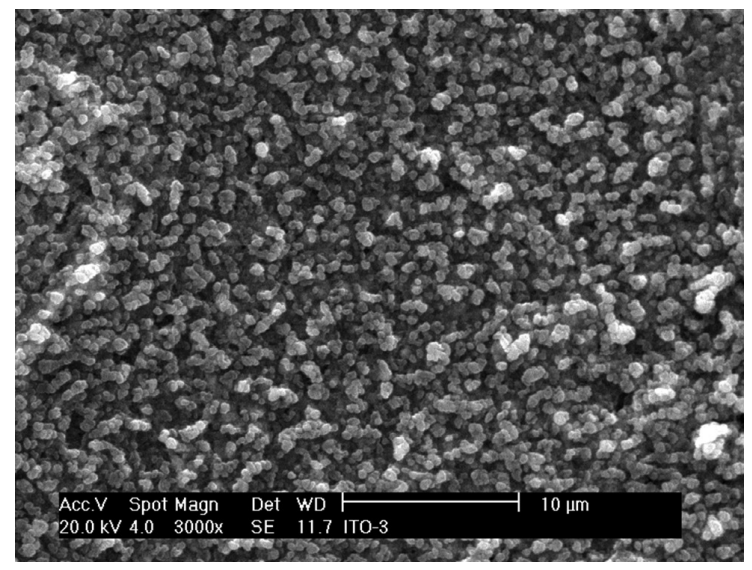

Figure 4. SEM image of the synthesized ITO film.
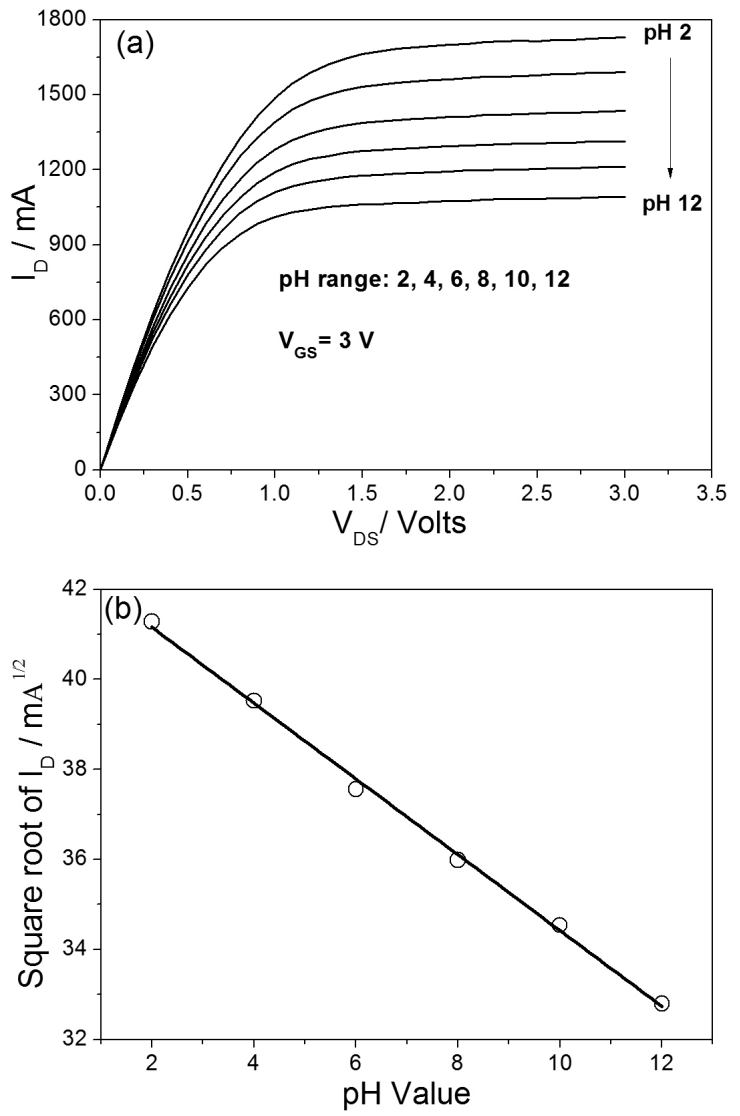

Figure 5. $I_{D}-V_{D S}$ characteristics for constant $V_{G S}$ of the ITO film as separative extend gate-FET in the $\mathrm{pH}$ range from 2 to 12 : (a) $\mathrm{I}_{\mathrm{D}}-\mathrm{V}_{\mathrm{DS}}$ characteristics, and (b) square root of $\mathrm{I}_{\mathrm{D}}$.
Figure 6a shows the corresponding $\mathrm{I}_{\mathrm{D}}-\mathrm{V}_{\mathrm{GS}}$ characteristics curves of the ITO as SEGFET $\mathrm{pH}$ sensor. As shown in Figure $6 \mathrm{~b}$, a linear response of $\mathrm{V}_{\mathrm{GS}}$ in the $\mathrm{pH}$ range of 2-12 may be observed. The sensitivities of the ITO SEGFET was calculated from the slope in the Figure $6 \mathrm{~b}$ for fixed $\mathrm{I}_{\mathrm{D}}=200 \mu \mathrm{A}$. ITO films presented a sensitivity about $53 \mathrm{mV} / \mathrm{pH}$ unity, close to the expected Nernstian theoretical value $(59,15 \mathrm{mV} / \mathrm{pH})^{26}$ to $\mathrm{pH}$ sensors and in and in good agreement with commercial ITO films $\mathrm{pH}$ sensors ${ }^{5}$, which presented $58 \mathrm{mV} / \mathrm{pH}$ of sensitivity ${ }^{5}$. Comparing with other synthetized ITO films, a sensitivity of $50 \mathrm{mV} / \mathrm{pH}$ was found by Lue et al. ${ }^{27}$ using ITO deposited on flexible polyethylene terephthalate (PET) by RF sputtering ${ }^{27}$. ITO films fabricated via anodic oxidation exhibited a sensitivity of ca. $54 \mathrm{mV} / \mathrm{pH}$ in a $\mathrm{pH}$ range from 2 to $12^{28}$. Therefore, our results indicate that the CVD technique is an alternative route to construct $\mathrm{pH}$-sensitive materials in a simple and low-cost way. In the other words, the results indicate that active sites in ITO films are involved in the formation of a charged double layer with the distribution of the potential between the film and the glass surface.

The ITO sensitivity may be explained by the well-known site-binding model theory ${ }^{29}$. According to this theory, three sites can be found on ITO surface, viz., negatively charged ITO- groups, neutral ITOH groups and positively charged
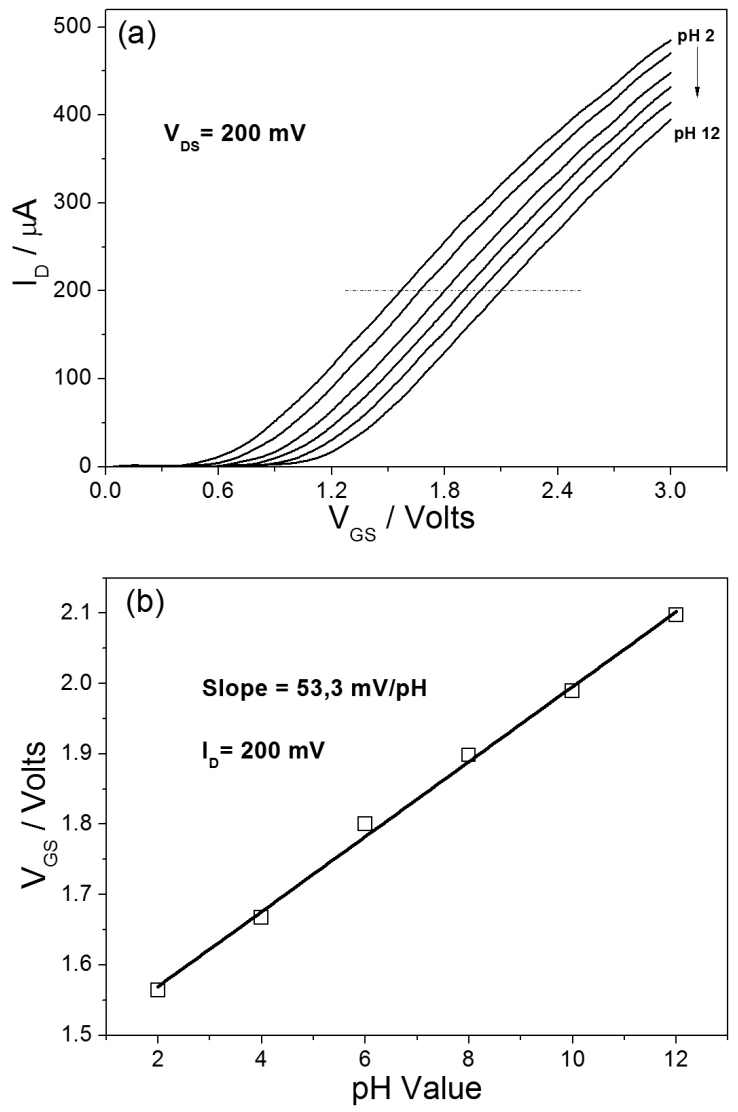

Figure 6. $I_{D}-V_{G S}$ characteristics for constant $V_{D S}$ of the ITO film as separative extend gate-FET in the $\mathrm{pH}$ range from 2 to 12 : (a) $\mathrm{I}_{\mathrm{D}}-\mathrm{V}_{\mathrm{GS}}$ characteristics, and (b) sensitivity calculated when $I_{D}$ was fixed in $200 \mu \mathrm{A}$. 
$\mathrm{ITOH}^{+}$groups. The total surface charge can be altered by complex formation on ITO surface. Upon changing electrolyte $\mathrm{pH}$, a change in the protons concentration occurs at ITO surface, modulating the drain-source current in the SEGFET device.

\section{Conclusions}

This study presented the ITO film deposited on glass substrates by low cost CVD spray system. Homogeneous ITO films with low resistivity and high optical transmittance were obtained. The $\mathrm{pH}$ sensing characteristics of the films were also analyzed using a SEGFET configuration. ITO

\section{References}

1. Tahar RBH, Ban T, Ohya Y and Takahashi Y. Tin doped indium oxide thin films: electrical properties. Journal of Applied Physics. 1998; 83(5):2631-2645. http://dx.doi. org/10.1063/1.367025

2. Saim HB, Campbell DS and Avaritsiotis JA. Indium tin oxides (ITO) thick-films for solar-cells. Solar Energy Materials. 1986; 13(2):85-96. http://dx.doi.org/10.1016/01651633(86)90037-7

3. Zhu F, Zhang K, Guenther E and Jin CS. Optimized indium tin oxide contact for organic light emitting diode applications. Thin Solid Films. 2000; 363(1-2):314-317. http://dx.doi. org/10.1016/S0040-6090(99)01003-2

4. Betz U, Olsson MK, Marthy J, Escola MF and Atamny F. Thin films engineering of indium tin oxide: Large area flat panel displays application. Surface \& Coatings Technology. 2006; 200(20-21):5751-5759. http://dx.doi. org/10.1016/j.surfcoat.2005.08.144

5. Yin LT, Chou JC, Chung WY, Sun TP and Hsiung SK. Study of indium tin oxide thin film for separative extended gate ISFET. Materials Chemistry and Physics. 2001; 70(1):12-16. http:// dx.doi.org/10.1016/S0254-0584(00)00373-4

6. Crespilho FN, Ghica ME, Gouveia-Caridade C, Oliveira ON $\mathrm{Jr}$ and Brett CMA. Enzyme immobilisation on electroactive nanostructured membranes (ENM): Optimised architectures for biosensing. Talanta. 2008; 76(4):922-928. PMid:18656679. http://dx.doi.org/10.1016/j.talanta.2008.04.054

7. Crespilho FN, Iost RM, Travain SA, Oliveira ON Jr and Zucolotto V. Enzyme immobilization on Ag nanoparticles/polyaniline nanocomposites. Biosensors and Bioelectronics. 2009; 24(10):3073-3077. PMid:19427191. http://dx.doi.org/10.1016/j.bios.2009.03.026

8. Matharu Z, Sumana G, Arya SK, Singh SP, Gupta V and Malhotra BD. Polyaniline Langmuir-Blodgett Film Based Cholesterol Biosensor. Langmuir. 2007; 23(26):13188-13192. PMid:18001068. http://dx.doi.org/10.1021/la702123a

9. Choi CK, English AE, Jun S-I, Kihm KD and Rack PD. An endothelial cell compatible biosensor fabricated using optically thin indium tin oxide silicon nitride electrodes. Biosensors and Bioelectronics. 2007; 22(11):2585-2590. PMid:17113768. http://dx.doi.org/10.1016/j.bios.2006.10.006

10. Bergveld P. Thirty years of ISFETOLOGY - what happened in the past 30 years and what may happen in the next 30 years. Sensors and Actuators B: Chemical. 2003; 88(1):1-20. http:// dx.doi.org/10.1016/S0925-4005(02)00301-5

11. Chi LL, Chou JC, Chung WY, Sun TP and Hsiung SK. Study on extended gate field effect transistor with tin oxide sensing films presented a Nerstian $\mathrm{pH}$ response sensitivity of ca. 53 $\mathrm{mV} / \mathrm{pH}$. The use of CVD process in junction with SEGFET configuration represents a low cost alternative and appears to be beneficial for real applications in the fabrication of membranes for $\mathrm{pH}$ sensors and as a sensitive substrate for biosensors since $\mathrm{H}^{+}$is the product of several oxireductase enzymes.

\section{Acknowledgements}

The authors are grateful to CNPq, CAPES, FAPEMIG and FAPESP for the financial support.

membrane. Materials Chemistry and Physics. 2000; 63(1):1923. http://dx.doi.org/10.1016/S0254-0584(99)00184-4

12. Fernandes EGR, Vieira NCS, De Queiroz AAA, Guimarães FEG and Zucolotto V. Immobilization of Poly(propylene imine) Dendrimer/Nickel Phtalocyanine as Nanostructured Multilayer Films To Be Used as Gate Membranes for SEGFET pH Sensors. Journal of Physical Chemistry C. 2010; 114(14):6478-6483. http://dx.doi.org/10.1021/jp9106052

13. Zhang K, Zhu F, Huan CHA and Wee ATS. Indium tin oxide films prepared by radio frequency magnetron sputtering method at a low processing temperature. Thin Solid Films. 2000; 376(12):255-263. http://dx.doi.org/10.1016/S0040-6090(00)01418-8

14. Wan N, Wang T, Sun H, Chen G, Geng L, Gan X et al. Indium tin oxide thin films for silicon-based electro-luminescence devices prepared by electron beam evaporation method. Journal of Non-Crystalline Solids. 2010; 356(18-19):911-916. http:// dx.doi.org/10.1016/j.jnoncrysol.2009.12.026

15. Zhinong Y, Yuqiong L, Fan X, Zhiwei Z and Wei X. Properties of indium tin oxide films deposited on unheated polymer substrates by ion beam assisted deposition. Thin Solid Films. 2009; 517(18):5395-5398. http://dx.doi.org/10.1016/j. tsf.2008.12.057

16. Adurodija FO, Izumi H, Ishihara T, Yoshioka H, Yamada K, Matsui $\mathrm{H}$, et al. Highly conducting indium tin oxide (ITO) thin films deposited by pulsed laser ablation. Thin Solid Films. 1999; 350(1-2):79-84. http://dx.doi.org/10.1016/S00406090(99)00278-3

17. Kundu S and Biswas PK. Synthesis and photoluminescence property of nanostructured sol-gel indium tin oxide film on glass. Chemical Physics Letters. 2005; 414(1-3):107-110. http://dx.doi.org/10.1016/j.cplett.2005.08.062

18. Sawada Y, Kobayashi C, Seki S and Funakubo H. Highlyconducting indium-tin-oxide transparent films fabricated by spray CVD using ethanol solution of indium (III) chloride and tin (II) chloride. Thin Solid Films. 2002; 409(1):46-50. http:// dx.doi.org/10.1016/S0040-6090(02)00102-5

19. Maki K, Komiya N and Suzuki A. Fabrication of thin films of ITO by aerosol CVD. Thin Solid Films. 2003; 445(2):224-228. http://dx.doi.org/10.1016/j.tsf.2003.08.021

20. Ramadan AA, Gould RD and Ashour A. On the Van der Pauw method of resistivity measurements. Thin Solid Films 1994; 239(2):272-275. http://dx.doi.org/10.1016/00406090(94)90863-X

21. Han H, Adams D, Mayer JW and Alford TL. Characterization of the physical and electrical properties of indium tin oxide on polyethylene napthalate. Journal of Applied Physics. 2005; 98(8):1-8. http://dx.doi.org/10.1063/1.2106013 
22. Fallah HR, Ghasemi $M$ and Hassanzadeh A. Influence of heat treatment on structural, electrical, impedance and optical properties of nanocrystalline ITO films grown on glass at room temperature prepared by electron beam evaporation. Physica E-Low-Dimensional Systems \& Nanostructures. 2007; 39(1):69-74. http://dx.doi.org/10.1016/j. physe.2007.01.003

23. Ibanez JG, Solorza O and Gomez-del-Campo E. Preparation of semiconducting materials in the laboratory. Production of CdS thin films and estimation of their band gap energy. Journal of Chemical Education. 1991; 68(10):872-875. http://dx.doi. org/10.1021/ed068p872

24. Brewer SH and Franzen S. Calculation of the electronic and optical properties of indium tin oxide by density functional theory. Chemical Physics. 2004; 300(1-3):285-293. http:// dx.doi.org/10.1016/j.chemphys.2003.11.039

25. Ma HL, Zhang DH, Ma P and Win SZ, Li SY. Preparation and properties of transparent conducting indium tin oxide films deposited by reactive evaporation. Thin Solid
Films. 1995; 263(1):105-110. http://dx.doi.org/10.1016/00406090(95)06554-7

26. Janata $\mathrm{J}$ and Josowicz M. Nernstian and non-nernstian potentiometry. Solid State Ionics. 1997; 94(1-4):209-215. http:// dx.doi.org/10.1016/S0167-2738(96)00503-6

27. Lue CE, Wang IS, Huang CH, Shiao YT, Wang HC, Yang $\mathrm{CM}$ et al. $\mathrm{pH}$ sensing reliability of flexible ITO/PET electrodes on EGFETs prepared by a roll-to-roll process. Microelectronics Reliability. 2012; 52 (8):1651-1654. http:// dx.doi.org/10.1016/j.microrel.2011.10.026

28. Lin JL and Hsu HY. Study of Sodium Ion Selective Electrodes and Differential Structures with Anodized Indium Tin Oxide. Sensors. 2010; 10(3):1798-1809. PMid:22294900 PMCid:3264452. http://dx.doi.org/10.3390/s100301798

29. Yates DE, Levine S and Healy TW. Site-binding model of electrical double-layer at oxide-water interface. Journal of the Chemical Society-Faraday Transactions I. 1974; 70:18071818. http://dx.doi.org/10.1039/f19747001807 